\title{
Toksisitas Ekstrak Biji Mahoni Terhadap Ulat Plutella xylostella pada Daun Kubis
}

\section{Toxicity of Mahogany Seed Extract Against Plutella xylostella Caterpillars on Cabbage Leaves}

\author{
Ayu Putri Dwi Ariyanti*, Subagiya, Ato Sulistyo \\ Department of Agrotechnology, Faculty of Agriculture, Universitas Sebelas Maret, Surakarta, Indonesia \\ ${ }^{*}$ Corresponding author: ayupda@gmail.com
}

Received: March 12, 2019; Accepted: September 24, 2019; Published: April 1, 2020

\begin{abstract}
Plutella xylostella is one of cabbage's main pests. Botanical insecticides as alternative of chemical insecticides need to be expand, one of them is mahogany seed extract. Mahogany seed exctract contains saponin and flavonoid as reported mortal to $P$. xylostella. This study aimed to know the effective concentration of mahogany seed extract to manage $P$. xylostella different larva instar and to know $L_{50}$ value of mahogany seed extract to $P$. xylostella. This method used was completely randomized experimental design (CRD). Two factors used were mahogany seed exctract concentrations $\left(0 \mathrm{gL}^{-1}, 5 \mathrm{gL}^{-1}, 10 \mathrm{gL}^{-1}, 20 \mathrm{gL}^{-1}\right.$, and $\left.40 \mathrm{gL}^{-1}\right)$ and larva instar (first and third instar). Each treatment repeated four times. The results showed that percentage of larva mortality first instar higher than third instar. Concentration $20 \mathrm{gL}^{-1}$ of mahogany seed exctract effective to kill first instar larva, and concentration $40 \mathrm{gL}^{-1}$ effective for third instar. Percentage of pupa mortality highest in concentration $10 \mathrm{gL}^{-1}$ for first instar and concentration $40 \mathrm{gL}^{-1}$ for third instar larva. Antifeedant increased as concentration given, while the eating ability that higher in third instar was decreased. $\mathrm{LC}_{50}$ for first instar larva was $2,6 \mathrm{gL}^{-1}$ and third instar was $13,7 \mathrm{gL}^{-1}$, meaned that mahogany seed extract more toxic to first instar than third instar larva.
\end{abstract}

Key words: botanical insecticide, lethal concentration, mortality

Cite this as: Ariyanti, A. P. D., Subagiya, \& Sulistyo, A. (2020). Toksisitas Ekstrak Biji Mahoni Terhadap Ulat Plutella xylostella pada Daun Kubis. Agrosains : Jurnal Penelitian Agronomi 22(1): 1-6. DOI: http://dx.doi.org/10.20961/agsjpa.v22i1.28600

\section{PENDAHULUAN}

Kubis merupakan salah satu komoditas hortikultura yang banyak dimanfaatkan sebagai sayur. Tingginya tingkat konsumsi kubis memperbesar peluang pasar tanaman tersebut. Namun, budidaya tanaman kubis terkendala oleh hama yang menyebabkan kerugian. Plutella xylostella merupakan salah satu hama utama tanaman kubis yang mana menurut Ginting et al. $(2017)$ dapat menyebabkan kerusakan hingga $90 \%$, sehingga kubis tidak dapat membentuk krop.

Penggunaan insektisida kimia pada kubis berbahaya bagi lingkungan serta kesehatan karena kubis sering dikonsumsi dalam keadaan segar (mentah). Alternatif yang dapat dilakukan yakni dengan menggunakan insektisida nabati yang berasal dari tumbuhan. Rusandi et al. (2016) mengemukakan kelebihan dari insektisida nabati, yakni tidak menimbulkan pencemaran karena sifatnya yang mudah terurai dan residu cepat hilang, sehingga relatif aman bagi makhluk hidup lainnya.

Salah satu bahan yang dapat digunakan sebagai insektisida nabati adalah biji mahoni (Swietenia mahagoni) yang mengandung flavonoid dan saponin. Menurut Lina (2016) flavonoid dapat mengakibatkan denaturasi protein, sehingga larva kekurangan energi karena bahan makanan tidak tersalurkan ke tubuh. Saponin berinteraksi dengan menurunkan tegangan permukaan membran sel sehingga permeabilitas meningkat (Wina, 2012). Hal tersebut dapat mengakibatkan terjadinya kebocoran sel diikuti kematian sel dan lambat laun mengakibatkan kematian serangga. Tekeli et al. (2007) menggolongkan saponin sebagai racun sistemik karena dapat menembus ke seluruh jaringan tubuh sehingga mematikan serangga.

Berdasarkan penelitian Heviyanti et al. (2016) diketahui bahwa ekstrak biji mahoni pada konsentrasi $0,78 \mathrm{ml} / 100 \mathrm{ml}$ larutan methanol efektif membunuh larva P. xylostella pada tanaman sawi di lapang. Penelitian Susanto (2013) menunjukkan konsentrasi ekstrak biji mahoni $25 \mathrm{gL}^{-1}$ mengakibatkan mortalitas larva $P$. xylostella sebesar $56,25 \%$ pada tanaman sawi dalam skala laboratorium dengan nilai lethal concentration 50 ( $\left.\mathrm{LC}_{50}\right)$ atau konsentrasi yang dapat menyebabkan kematian $50 \%$ larva uji sebesar $28,1 \mathrm{gL}^{-1}$. Tujuan dari penelitian ini adalah untuk mengetahui konsentrasi ekstrak biji mahoni yang 
efektif untuk mengendalikan larva $P$. xylostella serta pengaruhnya terhadap instar larva yang berbeda dan untuk mengetahui nilai LC $_{50}$ ekstrak biji mahoni terhadap P. xylostella.

\section{BAHAN DAN METODE}

Penelitian dilaksanakan bulan September 2018 sampai Januari 2019. Bahan dan alat yang digunakan dalam penelitian ini adalah larva P. xylostella, kubis, biji mahoni, air, madu, blender, mortar dan pestle, stoples, timbangan, saringan, kurungan kasa, kuas, kertas milimeter dan gelas ukur. Penelitian menggunakan Rancangan Acak Lengkap (RAL) dengan dua faktor perlakuan, yakni konsentrasi ekstrak biji mahoni $\left(0 \mathrm{gL}^{-1}, 5 \mathrm{gL}^{-1}, 10 \mathrm{gL}\right.$ 1, $20 \mathrm{gL}^{-1}$, dan $40 \mathrm{gL}^{-1}$ air) serta instar larva (I dan III) yang diulang sebanyak empat kali. Setiap perlakuan menggunakan 20 ekor larva $P$. xylostella. Pelaksanaan penelitian meliputi perbanyakan (rearing) larva $P$. xylostella, pembuatan ekstrak biji mahoni, dan aplikasi larutan ekstrak biji mahoni. Peubah yang diamati adalah mortalitas larva, mortalitas pupa, hambatan aktivitas makan (antifeedant), kemampuan makan, dan Lethal Concentration 50 (LC 50$)$. Data mortalitas larva, antifeedant, dan kemampuan makan dianalisis menggunakan analisis ragam pada taraf $5 \%$ apabila terdapat beda nyata dilanjutkan dengan DMRT (Duncan Multiple Range Test) 5\%. Nilai LC 50 didapat dengan memasukkan data ke dalam menu Analyzed - Regression - Probit pada aplikasi SPSS. Respon Frequency dan Covariate dimasukkan jumlah larva yang mengalami kematian dan konsentrasi yang digunakan pada tiap ulangan. Significance Level pada Options dimasukkan 0,5.

\section{HASIL DAN PEMBAHASAN \\ Mortalitas larva Plutella xylostella}

Hasil penelitian pada Gambar 1 menunjukkan bahwa konsentrasi ekstrak biji mahoni $20 \mathrm{gL}^{-1}$ mampu membunuh $100 \%$ larva $P$. xylostella instar I, sedangkan persentase mortalitas larva instar III tertinggi pada konsentrasi $40 \mathrm{gL}^{-1}$. Kematian larva instar I lebih tinggi dibanding instar III. Persentase kematian semakin meningkat seiring konsentrasi yang diberikan.

Larva $P$. xylostella yang mati mengalami ciri-ciri lunak ketika disentuh dan lama-kelamaan berubah menjadi coklat berkerut terkadang sampai mengering, meskipun integumennya masih tampak utuh. Berdasarkan Gambar 1 tampak bahwa persentase mortalitas tertinggi larva $P$. xylostella instar I sebanyak $100 \%$ pada perlakuan $20 \mathrm{gL}^{-1}$ dan $40 \mathrm{gL}^{-1}$. Artinya ekstrak biji mahoni dengan konsentrasi $20 \mathrm{gL}^{-1}$ sudah mampu membunuh seluruh larva uji dan lebih efektif penggunaannya dibandingkan konsentrasi $40 \mathrm{gL}^{-1}$ karena lebih sedikit ekstrak yang digunakan. Mortalitas larva instar I dengan konsentrasi 5 dan $10 \mathrm{gL}^{-1}$ juga cukup tinggi, yakni $91,25 \%$ dan $95 \%$. Hasil pengujian tersebut menunjukkan bahwa ekstrak biji mahoni dalam konsentrasi yang rendah sudah mampu membunuh hampir seluruh larva uji. Menurut Utami dan Cahyati (2017) senyawa atau zat aktif yang bersifat toksik menyebabkan kematian pada serangga uji jika masuk ke dalam tubuh meskipun dengan konsentrasi yang rendah.

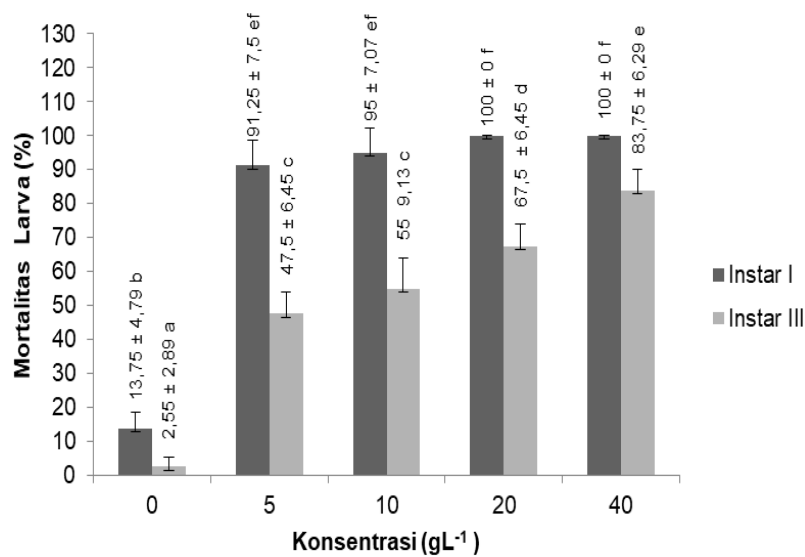

Keterangan: Antar angka yang diikuti huruf berbeda pada batang histogram menunjukkan berbeda nyata berdasarkan DMRT taraf $5 \%$ $\begin{array}{llll}\text { Gambar } & \text { 1. Histogram Mortalitas Larva }\end{array}$

Persentase mortalitas larva $P$. xylostella instar III tertinggi pada perlakuan $40 \mathrm{gL}^{-1}$ sebesar $83,75 \%$ yang menandakan konsentrasi tersebut paling efektif membunuh larva instar III. Mortalitas larva instar III terendah tampak pada kontrol sebesar 2,55\% karena tidak diberikan ekstrak biji mahoni.

Kematian larva $P$. xylostella disebabkan senyawa flavonoid dan saponin yang terkandung pada biji mahoni yang berperan sebagai insektisida. Flavonoid dapat mempengaruhi kemampuan makan larva karena menurunkan aktivitas enzim pencernaan. Lina (2016) mengemukakan flavonoid mengakibatkan denaturasi protein, sehingga bahan makanan tidak tersalurkan dan larva kekurangan energi. Saponin bekerja dengan menurunkan tegangan permukaan dinding saluran pencernaan menjadi rusak. Penyerapan makanan yang terkontaminasi saponin akan disalurkan ke seluruh tubuh melalui sistem peredaran darah menyebabkan reaksi hemolisis, sehingga mengganggu proses fisiologis larva termasuk aktivitas makan yang berdampak pada penghambatan pertumbuhan dan lama-kelamaan menyebabkan kematian (Budianto dan Tukiran, 2012; Sariri et al., 2018).

Persentase mortalitas larva $P$. xylostella instar I lebih tinggi dibandingkan dengan larva instar III karena perbedaan fisiologis. Larva instar I merupakan larva yang baru menetas dari telur, sehingga rentan terhadap pengaruh lingkungan sekitar, sedangkan larva instar III sudah memiliki ketahanan yang lebih tinggi. Sebagaimana yang dinyatakan Dono et al. (2012) bahwa jumlah larva yang mengalami kematian akibat pengaruh insektisida berbeda antar instar disebabkan perbedaan tingkat detoksifikasi racun pada tubuh, sehingga respon kematian juga berbeda.

Mortalitas larva $P$. xylostella baik instar I maupun III semakin meningkat mengikuti konsentrasi ekstrak biji mahoni yang diberikan. Hasil tersebut menunjukkan bahwa kandungan racun pada ekstrak 
biji mahoni semakin efektif pada tingkat konsentrasi yang lebih tinggi. Tanor (2014) mengemukakan semakin tinggi konsentrasi ekstrak yang diaplikasikan, maka mortalitas larva semakin meningkat karena bahan aktif yang terkandung juga semakin tinggi, sehingga kemampuan membunuh semakin besar.

\section{Mortalitas pupa $\boldsymbol{P}$. xylostella}

Hasil penelitian pada Gambar 2 menunjukkan pada konsentrasi $20 \mathrm{gL}^{-1}$ dan $40 \mathrm{gL}^{-1}$ tidak ada larva $P$. xylostella instar I yang berhasil melanjutkan kehidupan hingga ke fase pupa. Persentase mortalitas pupa dari larva instar I tertinggi pada konsentrasi $10 \mathrm{gL}^{-1}$, sedangkan larva instar III pada $40 \mathrm{gL}^{-1}$. Kematian pupa semakin meningkat mengikuti konsentrasi.

Pupa $P$. xylostella yang berhasil terbentuk merupakan larva yang mampu melanjutkan fase kehidupannya, sedangkan pupa yang gagal terbentuk akan berubah warna menjadi coklat kehitaman dengan tekstur keras dan tidak dapat menjadi imago. Menurut Begna dan Damtew (2016) insektisida nabati dapat memberikan efek terhadap fase pertumbuhan serangga berupa ketidaknormalan secara morfologi. Javier et al. (2019) menambahkan efek fisiologi yang diakibatkan oleh senyawa dalam insektisida nabati menyebabkan larva gagal untuk membentuk pupa.

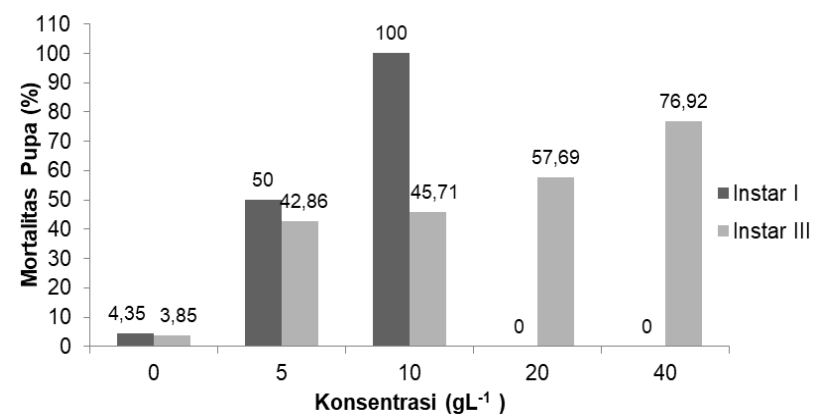

Keterangan: Tidak ada pupa yang terbentuk dari larva instar I konsentrasi 20 dan $40 \mathrm{gL}^{-1}$

Gambar 2. Histogram Mortalitas Pupa
P. xylostella

Tidak ada pupa yang berhasil terbentuk dari larva instar I di atas konsentrasi $10 \mathrm{gL}^{-1}$ ekstrak biji mahoni, namun mortalitas pupa mencapai $50 \%$ pada perlakuan $5 \mathrm{gL}^{-1}$ dan $100 \%$ pada perlakuan $10 \mathrm{gL}^{-1}$ seperti yang tampak pada Gambar 2. Sebaliknya, larva instar III dari seluruh konsentrasi perlakuan berhasil melanjutkan hingga ke fase pupa dengan persentase mortalitas tertinggi pada perlakuan $40 \mathrm{gL}$ 1 sebesar $76,92 \%$. Persentase mortalitas pupa dari larva instar I lebih tinggi dibandingkan larva instar III karena persentase mortalitas larva instar I lebih tinggi, sehingga lebih sedikit larva yang sanggup bertahan hidup dan dapat menyelesaikan fase pupa. Sebagaimana yang dinyatakan Hasnah (2009) bahwa proses metabolisme dari larva membutuhkan banyak energi, sedangkan lebih banyak energi yang digunakan untuk detoksifikasi, sehingga pertumbuhan dan perkembangan larva terganggu.
Persentase mortalitas pupa $P$. xylostella semakin meningkat sesuai konsentrasi yang diberikan. Peningkatan ini dipengaruhi jumlah pupa awal yang terbentuk, yakni semakin tinggi konsentrasi yang diberikan semakin sedikit pupa yang terbentuk karena lebih banyak larva yang mati setelah mengonsumsi kubis yang diberi insektisida. Hal ini berarti bahwa larva memiliki peluang yang kecil untuk bertahan melanjutkan siklus hidupnya setelah pengaplikasian insektisida. Serangga yang memakan bahan aktif tetapi tidak resisten menurut Tanor (2014) bertahan hidup dengan memaksimalkan penggunaan energi dari tubuh sebelum akhirnya mati, sementara serangga yang toleran akan berhasil melanjutkan hidup sampai tahap pupa atau imago.

Waktu yang diperlukan larva untuk menjadi pupa dan pupa menjadi imago pada perlakuan ekstrak biji mahoni tidak lebih cepat atau lebih lambat daripada kontrol. Hal ini bertentangan dengan hasil penelitian Sari et al. (2013) yakni stadia larva dan pupa yang berhasil melanjutkan hidup menjadi lebih pendek akibat racun yang terdapat pada insektisida nabati, sehingga larva dan pupa akan menjadi pupa dan imago lebih cepat dari keadaan normal. Herminanto (2006) menambahkan bahwa larva dan pupa mengalami pergantian kutikula (molting) sebelum dewasa. Apabila perlakuan yang diberikan tidak menyebabkan kematian pada stadium muda, maka dapat terjadi gangguang fisiologi maupun fisik sehingga stadium berjalan lebih lama atau lebih cepat dan ukuran lebih kecil dari normal.

Pupa yang berhasil terbentuk pada larva yang diberi perlakuan ekstrak biji mahoni juga tidak seluruhnya mampu menjadi imago. Agazali et al. (2015) menyatakan senyawa toksik yang diaplikasikan masih terbawa hingga ke fase pupa yang mempengaruhi pembentukan fase imago. Keberhasilan pembentukan imago normal menurut Dono et al. (2012) disebabkan perbedaan mekanisme pertahanan diri tiap individu karena individu yang memiliki ketahanan diri tinggi mampu menghilangkan racun dalam tubuh, sehingga pupa kembali ke ukuran normal dan imago keluar untuk menetaskan telur secara normal pula.

\section{Hambatan aktivitas makan (Antifeedant)}

Hasil penelitian pada Gambar 3 menunjukkan bahwa konsentrasi ekstrak biji mahoni $40 \mathrm{gL}^{-1}$ paling efektif dalam menghambat aktivitas makan larva $P$. xylostella. Tidak terdapat gangguan makan pada larva yang diberi kubis kontrol. Hambatan aktivitas makan mempengaruhi luas daun kubis dan mortalitas larva.

Hasil penelitian pada Gambar 3 menunjukkan terjadi peningkatan hambatan aktivitas makan (antifeedant) larva $P$. xylostella sesuai dengan konsentrasi ekstrak biji mahoni yang diberikan. Konsentrasi $0 \mathrm{gL}^{-1}$ baik larva instar I maupun III menunjukkan hambatan makan sebanyak $0 \%$ yang berarti bahwa tanpa adanya insektisida, aktivitas makan larva $P$. xylostella tidak mengalami gangguan, sehingga kerusakan yang terjadi lebih tinggi daripada kubis yang diaplikasikan insektisida. Hambatan 
aktivitas makan larva $P$. xylostella tertinggi pada konsentrasi $40 \mathrm{gL}^{-1}$, yakni 55,64\% untuk larva instar I dan 49,65\% untuk instar III, sehingga dapat dikatakan konsentrasi ekstrak biji mahoni $40 \mathrm{gL}^{-1}$ paling efektif dalam menghambat aktivitas makan larva $P$. xylostella dibandingkan konsentrasi lain yang diberikan.

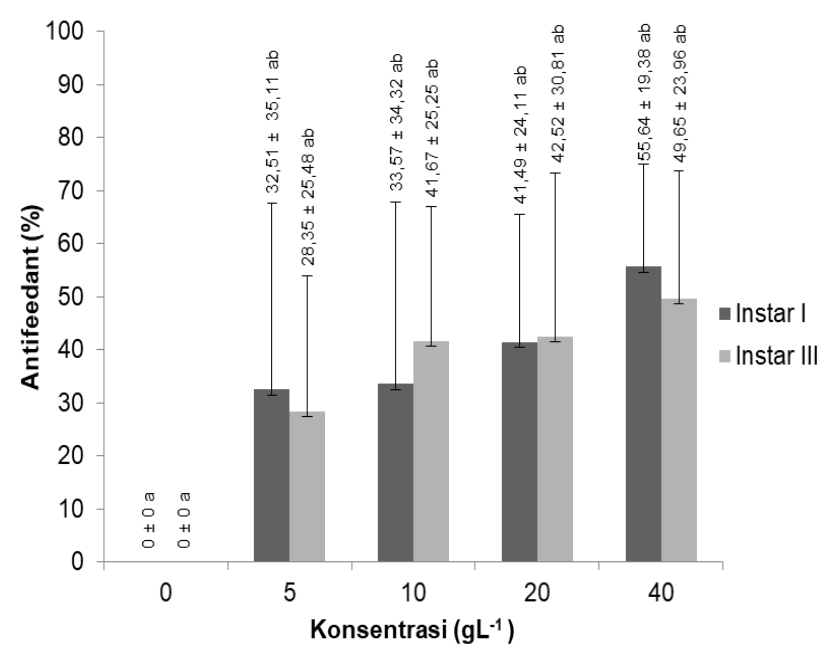

Keterangan: Antar angka yang diikuti huruf berbeda pada batang histogram menunjukkan berbeda nyata berdasarkan DMRT taraf $5 \%$.

Gambar 3. Histogram Antifeedant Ekstrak Biji Mahoni terhadap Larva P. xylostella

Senyawa flavonoid dan saponin dalam biji mahoni bersifat antifeedant yang mengakibatkan serangga menghentikan aktivitas makannya, baik sementara maupun permanen. Dono et al. (2010) mengemukakan antifeedant adalah senyawa kimia yang memiliki sifat menghambat aktivitas makan serangga. Antifeedant tidak bersifat membunuh, mengusir, dan menjerat serangga secara langsung, namun hanya menghambat nafsu makan (feeding inhibition). Antifeedant dapat menghambat pertumbuhan serangga karena pengaruh bahan aktif yang menurunkan akivitas makan larva, sehingga energi berkurang serta fungsi organ yang menghasilkan hormon pertumbuhan terganggu. Javier et al. (2016) menambahkan antifeedant merupakan zat yang terkandung dalam tumbuhan yang dapat mengubah perilaku serangga terhadap penolakan makan, seperti repellents yang mengusir serangga dari tanaman sebelum terjadinya aktivitas makan.

Penghambatan makan ini berhubungan dengan luas kubis yang dimakan dan mortalitas larva. Semakin tinggi hambatan aktivitas makan, maka luas daun atau kerusakan semakin rendah. Aktivitas makan yang semakin rendah akan menghambat pertumbuhan larva karena kurangnya nutrisi yang diperlukan, dengan demikian meningkatkan populasi larva yang mengalami kematian. Khaidir dan Hendrival (2013) menambahkan efek penghambatan aktivitas makan dapat menurunkan populasi hama karena mengakibatkan serangga menjadi lemah serta perkembangan tertunda.

\section{Kemampuan makan}

Hasil penelitian pada Gambar 4 menunjukkan bahwa luas daun kubis yang dimakan larva $P$. xylostella paling besar pada kontrol dan semakin menurun pada konsentrasi ekstrak biji mahoni yang semakin tinggi. Luas daun kubis yang dimakan larva instar III lebih besar dari larva instar I.

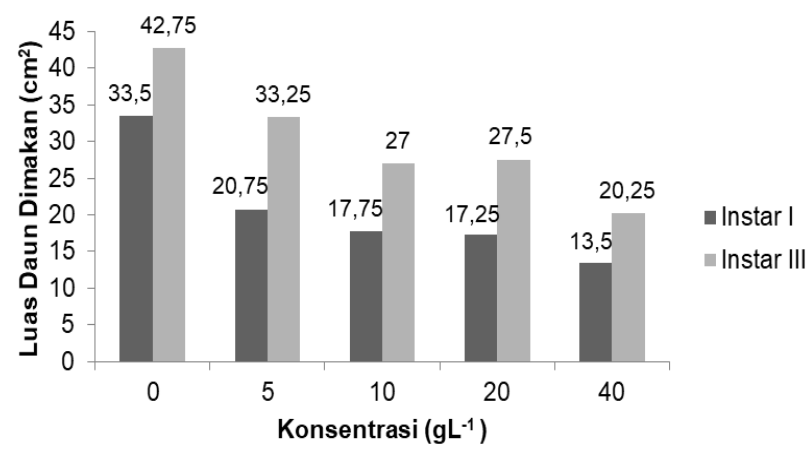

Gambar 4. Histogram Luas Daun Kubis yang Dimakan Larva $P$. xylostella.

Hasil pengujian menunjukkan luas kubis yang dimakan larva $P$. xylostella tertinggi pada kontrol sebesar 33,5 $\mathrm{cm}^{2}$ untuk larva instar I dan $42,75 \mathrm{~cm}^{2}$ untuk instar III (Gambar 4). Larva yang memakan kubis dengan pemberian insektisida ekstrak biji mahoni masih aktif makan, namun lama-kelamaan terjadi penurunan nafsu makan. Larva menjadi lemah dan pasif, sehingga lama-kelamaan akan mati. Halhal yang dihadapi serangga untuk memulai aktivitas makan menurut Khaidir dan Hendrival (2013) yakni rangsangan inisiasi makan (feeding stimulant) dalam tanaman sebagai isyarat pengenalan jenis makanan dan menjaga aktivitas makan, serta deteksi senyawa asing (foreign compound) sebagai penghambat makan yang akan memperpendek atau menghentikan aktivitas makan.

Aktivitas makan larva pada kubis yang diberi perlakuan lebih rendah daripada kubis tanpa aplikasi insektisida. Hal ini memperkuat pernyataan bahwa ekstrak biji mahoni mengandung senyawa yang menghambat aktivitas makan (antifeedant) larva $P$. xylostella, yakni flavonoid dan saponin. Dono dan Susanerwinur (2013) mengemukakan luas daun perlakuan yang dikonsumsi larva lebih sedikit daripada kontrol membuktikan ekstrak bersifat menghambat aktivitas makan. Penerimaan rangsangan larva terganggu, sehingga larva tidak dapat melakukan aktivitas makan secara normal yang berakibat nutrisi bagi larva tidak terpenuhi.

Senyawa flavonoid dan saponin yang terkandung dalam ekstrak biji mahoni menyebabkan kemampuan makan larva P.xylostella menurun. Flavonoid dan saponin bersifat antifeedant atau menghambat aktivitas makan larva. Antifeedant sendiri menurut Hermawan et al. (2010) bekerja dengan menghambat rangsangan makanan karena sistem saraf dan pencernaan terganggu, sehingga larva mengonsumsi makanan dalam jumlah lebih sedikit. Penurunan kemampuan makan tersebut diduga menjadi salah satu penyebab mortalitas larva dan pupa. Aktivitas makan larva yang menurun akibat insektisida menurut Sapindal et al. (2018) menyebabkan larva 
menjadi lemah, pertumbuhan terhambat, bahkan menyebabkan pupa dan imago mati.

Selain racun pada ekstrak biji mahoni tersebut, faktor lain yang mempengaruhi luas daun dimakan adalah jumlah larva yang masih dapat bertahan hidup dan melakukan aktivitas makan. Jumlah larva yang berhasil melanjutkan hidup setelah pengaplikasian ekstrak biji mahoni semakin menurun seiring dengan kenaikan konsentrasi yang diberikan, sehingga luas kubis yang dimakan pun semakin sedikit. Menurut Toana (2007) jumlah larva mempengaruhi intensitas serangan $P$. xylostella dimana semakin rendah kepadatan populasi larva maka jumlah daun kubis yang rusak pun semakin berkurang.

Kubis yang dimakan oleh larva $P$. xylostella instar III lebih banyak dibandingkan larva instar I. Luas kubis yang dimakan larva instar III paling sedikit pada konsentrasi $40 \mathrm{gL}^{-1}$ yakni sebesar $20,25 \mathrm{~cm}^{2}$. Hal tersebut disebabkan aktivitas makan serta jumlah larva instar III lebih tinggi dari instar I. Gowri dan Manimegalai (2016) menyatakan larva instar III dan IV memiliki aktivitas makan yang lebih besar daripada instar I dan II, namun akan mengurangi aktivitas tersebut menjelang fase pupa.

\section{Lethal concentration $\mathbf{5 0}\left(\mathbf{L C}_{50}\right)$}

Berdasarkan jumlah kematian larva yang didapat kemudian dilakukan uji probit untuk mengetahui lethal concentration. Lethal concentration 50 menurut Rahmawati et al. (2018) adalah konsentrasi yang menyebabkan kematian pada $50 \%$ serangga uji. Ariyanti et al. (2017) menambahkan tujuan penggunaan metode probit yakni untuk mempermudah perhitungan kematian.

Tabel 1. Hasil Analisis Probit LC 50

\begin{tabular}{cccc}
\hline \multirow{2}{*}{$\begin{array}{c}\text { Instar } \\
\text { Larva }\end{array}$} & \multirow{2}{*}{ Nilai LC50 } & \multicolumn{2}{c}{ Selang Kepercayaan (95\%) } \\
\cline { 3 - 4 } & & $\begin{array}{c}\text { Batas } \\
\text { Bawah }\end{array}$ & $\begin{array}{c}\text { Batas } \\
\text { Atas }\end{array}$ \\
\hline Instar I & 2,589 & 0,927 & 3,987 \\
Instar III & 13,671 & 8,698 & 18,700 \\
\hline
\end{tabular}

Berdasarkan hasil analisis probit yang dilakukan, nilai $\mathrm{LC}_{50}$ dari larva $P$. xylostella instar I sebesar 2,6 $\mathrm{gL}^{-1}$ dan larva instar III sebesar 13,7 $\mathrm{gL}^{-1}$ (Tabel 1). Hasil tersebut menunjukkan bahwa konsentrasi ekstrak biji mahoni yang dapat membunuh $50 \%$ larva uji $P$. xylostella instar I sebanyak 2,6 $\mathrm{gL}^{-1}$, jauh lebih rendah dibandingkan larva instar III yang baru mengalami kematian $50 \%$ pada konsentrasi $13,7 \mathrm{gL}$ 1. Menurut Suryani et al. (2017) nilai LC50 yang semakin kecil menunjukkan tingkat racun suatu senyawa semakin tinggi atau dapat dikatakan semakin tinggi toksisitasnya. Hal ini berarti ekstrak biji mahoni lebih toksik terhadap larva $P$. xylostella instar I dibanding instar III disebabkan larva $P$. xylostella instar I baru menetas dari telur dan masih sangat rentan terhadap pengaruh lingkungan, sedangkan larva instar III sudah mampu beradaptasi.

\section{KESIMPULAN}

Konsentrasi ekstrak biji mahoni sebesar $20 \mathrm{gL}^{-1}$ efektif untuk mengendalikan larva instar I $P$. xylostella, sedangkan pada larva instar III konsentrasi efektif adalah $40 \mathrm{gL}^{-1}$. Hambatan aktivitas makan (antifeedant) larva semakin meningkat seiring dengan peningkatan konsentrasi yang diberikan, yang berarti bahwa kemampuan makan semakin menurun. Konsentrasi ekstrak biji mahoni 2,6 $\mathrm{gL}^{-1}$ merupakan konsentrasi lethal untuk instar I, dan 13,7 $\mathrm{gL}^{-1}$ untuk larva instar III.

\section{DAFTAR PUSTAKA}

Agazali, F., Hoesain, M., \& Prastowo, S. (2015). Efektivitas insektisida nabati daun tanjung dan daun pepaya terhadap mortalitas ulat grayak (Spodoptera litura F.). Berkala IImiah Pertanian 1(1):1-5.

Ariyanti, R., Yenie, E., \& Elystia, S. (2017). Pembuatan pestisida nabati dengan cara ekstraksi daun pepaya dan belimbing wuluh. Jom Fteknik 4(2):1-9.

Begna, F., \& Damtew, T. (2016). The effect of plant extract for managing diamondback moth, Plutella xylostella L. (Lepidoptera : Plutellidae) on head cabbage in Ethiopia. J of Biology, Agriculture and Healthcare 6(5):72-80. DOI:10.13140/RG.2.2.35870.84803.

Budianto, F., \& Tukiran. (2012). Bioinsektisida dari tumbuhan bakau merah (Rhizhopora stylosa. Griff) (Rhizophoraceae). UNESA J of Chemistry 1(1):19-25.

Dono, D., Ismayana, S., Idar, Prijono, D., \& Muslikha, I. (2010). Status dan mekanisme resistensi biokimia Crocidolomia pavonana (F.) (Lepidoptera: Crambidae) terhadap insektisida organofosfat serta kepekaannya terhadap insektisida botani ekstrak biji Barringtonia asiatica. J Entomol. Indon. 7(1):9-27.

Dono, D., Natawigena, W. D., \& Majid, M, G. (2012). Bioactivity of methanolic seed extract of Barringtonia asiatica L. (Kurz) (Lecythidaceae) on biological characters of Spodoptera litura (Fabricius) (Lepidoptera : Noctuidae). International Research $J$ of Agricultural Science and Soil Science 2(11):469-475.

Dono, D., \& Susanerwinur. (2013). Toksisitas dan anti oviposisi ekstrak metanol kulit jambu mete (Anacardium occidentale L.) (Anacardiaceae) terhadap Crocidolomia pavonana F. (Lepidoptera : Pyralidae). Bionatura J IImu-ilmu Hayati dan Fisik 15(2):79-82.

Ginting, M. S., Pelealu, J., \& Pinaria, B. A. N. (2017). Efektivitas beberapa insektisida nabati terhadap hama Plutella xylostella Linn. (Lepidoptera; Plutellidae) pada Tanaman Kubis (Brassica oleracea L.) di Kabupaten Minahasa. Agri-Sosio Ekonomi Unstrat 13(3A):295-302.

Gowri, G., \& Manimegalai, K. (2016). Biology of diamondback moth, Plutella xylostella (Lepidoptera: Plutellidae) of cauliflower under laboratory condition. International $J$ of Fauna and Biological Studies 3(5):29-31.

Hasnah, H. (2009). Efektivitas ekstrak buah mengkudu (Morinda citrifolia L.) terhadap 
mortalitas Plutella xylostella L. pada tanaman sawi. J Floratek 4:29-40.

Hermawan, W., Erawan, E. S., \& Hardiansyah, C. (2010). Efek antifidan Andrografolida terhadap aktivitas kelenjar pencernaan larva Plutella xylostella L. Bionatura J IImu-ilmu Hayati dan Fisik $12(1): 50-56$.

Herminanto. (2006). Pengendalian hama kubis Crocidolomia pavonana F. menggunakan ekstrak kulit buah jeruk. J Pembangunan Pedesaan 6(3):165-174.

Heviyanti, M., Husni, \& Rusdy, A. (2016). Efektifitas ekstrak biji mahoni (Swietenia mahogani Jacq.) terhadap mortalitas dan rata-rata waktu kematian larva Plutella xylostella pada tanaman sawi. J Agrosamudra 3(1):27-38.

Javier, A. M. V., Ocampo, V. R., Ceballo, F.A., \& Javier, P. A. (2016a). Insecticidal activity of four essential oils against diamondback moth, Plutella xylostella Linnaeus (Lepidoptera: Pyralidae). The Philippine Agricultural Scientist 99(2):156-163.

Javier, A. M. V., Ocampo, V. R., Ceballo, F. A., \& Javier, P. A. (2016b). Insecticidal activity of crude ethanolic extracts of selected Philippine plants against diamondback moth, Plutella xylostella. Philippine $J$ of Science 148(1):33-43.

Khaidir, \& Hendrival. (2013). Pengujian penghambatan aktivitas makan dari ekstrak daun Lantana camara L. (Verbenaceae) terhadap larva Plutella xylostella L. (Lepidoptera: Ypnomeutidae). J Floratek 8:35-44.

Lina, M. (2016). Pengaruh pemberian ekstrak daun legundi (Vitex trifolia) sebagai pestisida nabati pengendalian hama Plutella xylotella pada tanaman sawi (Brasscia juncea). J Biologi 5(4):34-40.

Rahmawati, S., Karimuna, S. R., \& Yasnani. (2018). Efektivitas lilin aromatik dari ekstrak kulit jeruk nipis (Citrus aurantifolia) sebagai insektisida alami terhadap lalat rumah (Musca domestica). J IImiah Kesehatan Masyarakat 3(3):1-8.

Rusandi, R., Mardhiansyah, M., \& Arlita, T. (2016). Pemanfaatan ekstrak biji mahoni sebagai pestisida nabati untuk mengendalikan hama ulat grayak (Spodoptera litura F) pada pembibitan Acacia crassicarpa A. Cunn. ex Benth. Jom Faperta UR (3)1:1-6.
Sapindal, E., Ong, K. H., \& King, P. J. H. (2018). Efficacy of Azadirachta excelsa vinegar against Plutella xylostella. International $J$ of Pest Management 64(1):39-44. DOI:10.1080/09670874.2017.1293866.

Sari, M., Lubis, L., \& Pangestiningsih, Y. (2013). Uji efektivitas beberapa insektisida nabati untuk mengendalikan ulat grayak (Spodoptera litura F.) (Lepidoptera : Noctuidae) di laboratorium. J Online Agroteknologi 1(3):560-569.

Sariri, A. K., Mulyono, M. W., \& Tari, A. I. N. (2018). The utilization of microbes as a fermentation agent to reduce saponin in Trembesi leaves (Sammanea saman). IOP Conference Series : Earth and Enviromental Science 142:1-5. DOI:10.1088/1755-1315/142/1/012041.

Suryani, A. I., Hariani, N., Majid, A. F., \& Risqa, S. (2017). Persentase mortalias ulat grayak terhadap pemberian eksrak daun bunga pukul empat. Bionature 18(2):118-122.

Susanto, W. (2013). Pengaruh aplikasi ekstrak biji mahoni (Swietenia mahagoni Jacq.) terhadap mortalitas ulat kubis (Plutella xylostella L.) (Lepidoptera : Plutellidae). Skripsi. Universitas Lampung, Lampung.

Tanor, M. N. (2014). Methanol extract of Barringtonia asiatica, Kurz. quite effective induce mortality of Spodopthera litura, Fabr. larvae on soybean plants. $J$ of Biology and Life Science 5(2):159-164. DOI:10.5296/jbls.v5i2.5587.

Tekeli, A., Celik, L., \& Kutlu, H. R. (2007). Plant extracts; a new rumen moderator in ruminant diets. $J$ of Tekirdag Agricultural Faculty 4(1):71-79.

Toana, M. H. (2007). Pengaruh konsentrasi ekstrak kulit jeruk nipis (Citrus aurantifolia S.) terhadap kepadatan populasi dan intensitas serangan Plutella xylostella L. (Lepidoptera : Plutellidae) pada tanaman kubis. Agroland 14(3):195-200.

Utami, I. W., \& Cahyati, W. H. (2017). Potensi ekstrak daun kamboja sebagai insektisida terhadap nyamuk Aedes aegypti. Higeia 1(1):22-28.

Wina, E. (2012). The use of plant bioactive compounds to mitigate enteric methane in ruminants and its application in Indonesia. J Wartazoa 22:24-34. 